\title{
MENTOR'S COMPETENCE MODEL USED TO BUILD A RELATIONSHIP WITH A CHILD LIVING IN A RESIDENTIAL CARE INSTITUTION
}

\section{Baidarova Olga ${ }^{1}$ \\ Udovenko Julia ${ }^{2}$}

DOI: http://dx.doi.org/10.30525/978-9934-571-27-5_3

Abstract. The purpose of the article is to generalize the research results of the integral parts of mentor's competence, which allows him/her to build relationships with a child living in a residential care institution and present the mentor's competence model created on the basis of this research. The research involved study of theoretical approaches in determining the content of the mentor's competencies, analysis of ongoing training programmes for people who want to become mentors in Ukraine, as well as consideration of the expertise in implementing Mentoring Project in the city of Kyiv and in Kyiv region during 2009-2018. The research have defined the primary tasks of the mentors in building their relationships with a child, aimed to provide personal assistance and help, and initially to prepare the child to live independently. It has been found out that content of mentors' training at an early stage of the project implementation was determined by the necessity to justify mentors' place in the social protection system for orphans in Ukraine, their role in the child's life and revealed the general social and psychological aspects of the training for effective interaction with children that have an experience of being displaced and living in a residential care institution. Identified gaps in the programme are caused by an insufficient orientation on children's needs in their protection against abuse and impact of other risk factors present in residential care institutions, as well as inadequate assistance in overcoming consequences of the psycho-traumatic experience during their residing in the institution. It has also been revealed that the broader context of mentor's activities was not sufficiently reflected in the

\footnotetext{
${ }^{1}$ Candidate of Psychological Sciences,

Assistant Lecturer at Department of Social Rehabilitation and Social Pedagogy,

Taras Shevchenko National University of Kyiv, Ukraine

${ }^{2}$ Candidate of Psychological Sciences,

Assistant Lecturer at Department of Social Rehabilitation and Social Pedagogy,

Taras Shevchenko National University of Kyiv, Ukraine
} 
programme. Such activities include their participation in the interdisciplinary team work, that carries out personalized social support of a child, as well as work on changing the legislative environment. To a great extent this situation can be explained by the innovation aspect of such activities at that time in Ukraine, by the lack of legal instruments that it could be regulated by and, which is one of the most important factors, the lack of any standardized training model on a state level for people who want to become mentors in order to complete the tasks assigned to them. A new competence based model of mentor's training has been submitted and became the basis of a renewed and enhanced Training Programme. The findings have resulted in recommendations on improvement of the Training Programme for mentors working with orphans and children deprived of parental care that has been adopted and translated into practices by the Ministry of Social Policy of Ukraine within a framework of scaling-up the Mentoring Project to the national level with the purpose of facilitating the social integration of the children belonging to the above mentioned category and in order to prepare them to live independently.

\section{Introduction}

The fact of renouncing the idea of raising children within the residential care institutions because of their negative influence on a mental and physical development of a child is starting to have a strategic, systemic and organized response in Ukraine at last. A reformation of the institutional childcare and educational systems has been initiated and it involves reduction in numbers of children who are brought up in the orphanages, transformation of the system of such institutions into a family-type children's homes with no more than 15 children at a time, as well as development of the system of affordable and good-quality services for families raising children in communities. In the meantime, while the reform continues, there are still $1.5 \%$ of children being raised in the old type institutions and for each of them the situation remains at least unfavorable, and very often it is really threatening.

There are more than 750 residential care and educational institutions for children in Ukraine but the number of children residing in them is over 100000 (and among them only $8 \%$ are orphans or children deprived of parental care). Children with disabilities, ones of juvenile and adolescent age, as well as siblings from multiple children families stay out of the family-based care such as adoption, custody, foster family, family-type chil- 
dren's home. While placing orphans and children deprived of parental care into family-based care, considerable difficulties arise with teenage children (11-18 years old) because people, willing to take care of the children, prefer adopting ones aged up to 5 and less often up to 10 years old.

Due to the fact that current forms of family-based care in Ukraine are not ready to assure the right of every orphan or a child deprived of parental care and to be raised in a family, the problem of searching the alternative forms of care for such children has become quite relevant. And mentoring is one of these forms of child care. While in many European countries, the USA and Australia mentoring programmes have history that go several decades back, in Ukraine this practice is still in its initial stages. Until now, it existed only at local levels, as a part of local initiatives or certain projects, such as a Mentoring Project "Odna Nadiya" ("One Hope") that was implemented in the city of Kyiv and Kyiv region. Within the framework of this project, a considerable experience has been accumulated, which has to be scientifically evaluated and used for making decisions and implementing changes on the national level.

Since 2016 mentoring has been introduced on the national level in Ukraine as an individual from of child care and support for children, who live in orphanages, as well as in institutions for children deprived of parental care, other types of institutions for children. First of all it is aimed on the preparation of a child for independent life through developing their capabilities, maintaining confidence in their own strengths, helping to set goals in their lives, building good relationships with other people, forming cultural, moral and spiritual values. It meant the importance of finding and training relevant and reliable people, friendly to every child, who can potentially become a child's mentor. Thus, the question of volunteers' training has arisen. They are people who will take responsibilities to complete these tasks, i.e. they will be ready and capable of building and maintaining personal relationships with the children who, in fact, were abandoned by other adults. For the development of mentoring practice in Ukraine it was necessary to analyze and reviewed the content of the mentors training based on competence approach.

Traditionally, the competence (Lat. competentia, which is a range of issues a person is quite familiar with and has some kind of knowledge and experience in them), is considered as gained in the process of integrated capabilities training of an individual consisting of knowledge, skills, expe- 
rience, values and attitudes which can be entirely translated into practice. The content of competences of the mentor, who works with a child living in a residential institution, is defined by the conditions of the living environment of such child and the tasks of the surrounding adults, responsible for their protection and support, in interacting with him/her.

Purpose of the research is to define the integral parts and the content of mentor's competences used for building relationships with a child living in an orphanage, an institution for children deprived of parental care or in other type of residential care institution for children.

\section{Tasks of the research:}

1. Conduct a theoretical analysis of the studies of mentor's competences content which is essential for interacting with a child living in a residential care institution.

2. Conduct analysis of existing training programmes for people willing to become mentors in Ukraine.

3. Empirically research current needs and support necessary for children living in residential care institutions.

4. Develop a model of the mentor's competence used for building relationships with a child living in an orphanage, an institution for children deprived of parental care or in other type of residential care institution for children.

In this research we used the following methods: theoretical analysis; generalization and modeling; document analysis; focused group interviews with the youth who had an experience of institutional care, as well as with the mentors of children, who live in residential care institutions.

\section{Mentor's competences required for interacting with a child living in a residential care institution}

Socialization of a foster child from a residential care institution is hindered by emotional stress (psycho-traumatic experience), social and economic problems and insufficient individual care, as well as the lack of adequate protection in the residential care institutions which can endanger children's life. A child's stay in the institution is connected with a number of existing risks for him/her determined by two factors.

The first factor is the necessity to overcome the previous negative experience acquired while living with a family, such as violence and lack of attention, under conditions that rarely contribute to rehabilitation and encouragement. Deprivation of family upbringing, that, as a rule, results 
in delayed mental development of a child, interferes with consciousness formation and distorts personality development and cannot be compensated in the environment of a closed-type institution. Unfavourable conditions in a residential care institution are connected with a specific communication system created between adults and children (regular orders, constant guidance and control, as well as scheduling etc.), staff turnover, limited circle of contacts, narrowing of the environment, absence of freedom of choice, differentiated approach to the children on the part of educators etc, which feed a sense of social alienation with a child, negligence to their personality in the society [4, p. 175]. Working in the system of such institutions cannot contribute to the creation of long-term, trust-based, stable and secure relationship between an adult and a child. Among the main factors causing the delay in mental development of a personality, difficulties in establishing a healthy attachment, in creating proper emotional comfort and safe environment for the socialization the first place goes to absence of an adult who would permanently take care of the child. The results of numerous studies, summarized in the work "Mentoring Programs and Youth Development: A Synthesis", indicate that a positive relation with at least one caring adult is an essential protective factor that helps such children to become competent and autonomous adults [14]. Social support on the part of the adults in the community, who are not his/her parents, provides transfer of the social capital and prevents from embarking on risky routes, which is the use of psychoactive substances, violence or criminal behaviour.

Another factor that conditions the need of presence of a caring adult in a child's life in a residential care institution, is connected with the fact that the child needs physical safety in order to defend himself/herself from the violence both on the part of his/her peers and the adults. The research has revealed that children living in residential care institutions belong to a vulnerable group and are considered at-risk as for child maltreatment [13; 11]. Violent behaviour on the part of the staff and children belonging to the community is a distinctive feature of places of deprivation of liberty. The research findings published in the Analytical report "Life journey of the residential care institution leavers, family-type orphanages and foster families" (2010) [1], has revealed numerous shocking facts of child maltreatment, which occurred to these children during their stay in the residential care institution.

According to the records of Disability Rights International [16], the highest risk is present for the disabled children who are often put into the 
poorest and the dirtiest parts of the institution premises, are deprived of any activities, stimulation or human contacts. Many children are subjected to physical restraints in order they cannot move, are kept in their beds or cradles where their legs and hands become atrophied because of immobility. Separated from the rest of society and deprived of family and friends' protection, these children suffer from beatings, rape and other forms of everyday abuse. Forced child labour is also quite common in this type of institutions. And what is more, children living in residential care institutions are subjected to the risk of sexual abuse, child sex trade, engagement in pornography or trafficking in children's organs.

Considerable part of these children will remain in state custody before they make transition to the adulthood, which means they will have to face problems typical for all the residential care institutions leavers. A young person needs accommodation, has to build their financial self-sufficiency, establish social contacts and so on. However, in most cases, these children are poorly adapted to self-sustained life. The research findings show that young people leaving residential care institutions are the ones of the most vulnerable and disadvantaged social groups. Thus, it is obvious that the researchers place emphasis on the need to provide various additional services to the care leavers [17]. The aim of social assistance, provided to a care leaver, is to help their form a position of an agent in their own life, acquire competencies essential for living independently [5], as well as prepare for life-sustaining activities in an open society [8]. Nowadays assistance in socialization of the residential care leavers in Ukraine includes training courses in life skills for the senior students and school leavers and the social assistance of the young people leaving residential care institutions is provided as a part of a social guidance. However, the previously indicated courses are less than effective, being generally just a formality, and do not introduce any real behavioral patterns. The social guidance is often carried out without taking into account personal needs of a child or without any consistent preparatory work with the community in order they accept a young person and help him/her integrate easily into society.

Training through providing behavioral patterns is conducted within the framework of independent training programmes and mentors' participation. Mentoring, in general, means building relationship between an adult and a young person on a "one-on-one" basis. These relationships are focused on facilitation of personal development of a mentored person through direct 
instructions and encouragement and, indirectly, through setting an example [15, p. 16-17]. Mentoring is not a type of family upbringing, so confidential relationship with a child can be arranged even under condition that the child lives in an institution. Constant relationship, presence of a reliable caring person, possibility of getting and feeling adult's support prevent negative consequences of institutionalization and develop child's potential, improve their chances for getting good education, work and creating their own longterm family relationship.

The aims of mentoring are preparation of a child living in an institution for independent living by developing their potential, self-confidence, facilitation in forming social relationships, cultural and moral values due to communication with mentor, acquisition of common experience, observing mentor's behaviour and mastering new skills. Task of the mentor is to help a child acquire social and life skills for the successful social and psychological adaptation and integration in society. An indispensable condition for completing this task for a mentor is understanding psychological development process regularities, age and individual peculiarities of a child's personality. Foster child faces a series of psychological problems that can be solved exactly with the help of a mentor: compensating psychological deprivation level; restoring trust to people; forming gender role identification and accepting their gender role; correcting social disadaptation; adopting and accepting ethical values; forming everyday skills of living in a family and motivating to create their own family. Mentor has to find the right approach to a child, reveal their abilities and interests. Trust is an indispensable condition of building a good relationship between child and mentor. On the grounds of confidential relationship it is possible to arrange cooperation, "overcome the obstacles together" on the way to adulthood not by imposing mentor's opinion but rather by supporting a child in decision making, discussing the alternatives and facilitating conscious choice. Mentor can teach a child: to see and understand the problem, to accept it, solve it or to realize their inability to cope with it independently and if so, to ask for help [6]. Feelings of security, stability, continuity and social support are strong indicators of a young person's success in overcoming long-term consequences after leaving a care institution.

Mentor's expectations of being able to substitute the whole range of social services necessary for young people for transition to independent living is erroneous. Mentors give instructions, support and serve as role 
models. Other support has to be granted in a traditional way [15, p. 17]. In their role mentor can become a resource for boarding school pedagogues, psychologists and social service counselors in a community. Competence mentoring facilitates modernization and rises efficiency of social institutions' performance in their work with the children of this target category.

Mentoring has to facilitate the following tasks in a child's development: socialization, professional orientation and assistance in learning. Through friendly relations, support and spending time together mentor facilitates building of a child's self-confidence, self-dignity and solicitously accompanies child in their life.

Consequently, there are the following mentoring areas [10]:

1. Assistance in learning and comprehensive development of a child: mentors help children learn at school (do their homework), master academic knowledge and encourage them to attend various hobby groups.

2. Socialization of the children (forming skills of self-sufficient life): mentors help improve the self-esteem of their foster children; support them in their attempts to implement new behaviour models; provide substantial spare time activities for children; help develop communicative abilities, as well as teach building relationship with different people; assist in elaboration of abilities to control emotions and communicate with unfamiliar people, as well as solve conflicts; boost personal responsibilities in children, encourage independent decision making; guide them in their professional orientation boosting their motivation; assist in forming everyday attainments of taking good care of themselves, buying products, cooking, as well as family life skills (relationship between husband and wife, budget planning, housekeeping); form in children correct gender attitudes, orientation on equality in a relationship between husband and wife; ensure legal awareness, prevention of the risks connected with human trafficking.

3. Teenagers' professional orientation: mentors should help teenagers define their future plans regarding their career and aim at goals accomplishment; mentors can use their own contacts and acquaintances in order to help teenagers meet specialists in various fields, find possibilities of employment, undergo necessary training; introduce foster children to different educational organizations (colleges, technical schools, higher educational institutions); teach teenagers the process of searching for a job, form skills of responsible attitude towards their job responsibilities, stable attitudes in their life etc. 


\section{Mentors training programmes}

In 2009 in Kyiv a non-governmental organization Odna Nadiya (One Hope) suggested the idea of mentoring development for the mentioned category of children and started implementing Mentoring Project "Odna Nadiya" ("One Hope") in collaboration with state (Child protection service of Kyiv city Council (Kyiv city State administration) executive body and Kyiv city centre of social services for families, children and the youth) and non-governmental organizations in the field of children care. This Project involves the search and preparation of mentors for orphans and children deprived of parental care, especially teenagers (13-18 year sold) living in centres of social and psychological rehabilitation for children, boarding schools and orphanages. Within the framework of realization of this Project, the Mentoring Programme for orphans and children deprived of parental care (hereinafter referred to as Mentoring Programme) was elaborated. The Aim of Mentoring Programme is social and psychological mentors training on interaction with orphans and children deprived of parental care regarding their preparation for independent life (considering their needs, interests, social environment of a child's development, their age and peculiarities of their mental and physical development). Tasks of the Mentoring Programme include: 1) search, training and further support of each child's mentor; 2) assistance to a child in developing their own potential, revealing their strong points, definition by a child of their individual goals and ways of their accomplishment; 3) formation of a child's skills and attainments needed for living independently; 4) formation of a positive motivation towards creating their own close-knit family, of life and professional self-determination skills, social competence skills and legal culture. The Mentoring Programme embraces various target groups, starting from preschool children to boarding institutions leavers under the age of 23 .

Work methodology, according to the Mentoring Programme, provides for two main fields of work: 1) preparation of the orphans and children deprived of parental care for participation in the Programme; 2) social and psychological training of citizens wishing to become mentors [10, p. 35-45].

Work area "Preparation of the orphans and children deprived of parental care for participation in Mentoring Programme" involves the following procedure: 1) meeting the staff and children of an institution; 2) coming into contact with children (at the premises of the institutions where those children live); 3) evaluation of children's needs and their social 
environment (aiming at further children and mentors reciprocal selection); 4) individual work planning with children. Implementation by the mentor of their individual working plan according to a child's needs and social environment will provide a differentiated and individual approach to the preparation of teenagers for independent living and social adaptation in general.

The operation algorithm in the area of "Social and psychological training of citizens wishing to become mentors" has the following stages: 1) conducting an awareness-raising campaign regarding the involvement of the community in mentoring; 2) first contact by telephone with citizens wishing to become mentors; 3) coordination meeting with the candidates; 4) primary psychological counseling; 5) visit to a family by the Programme's assistants (social worker/social counselor, psychologist); 6) educational workshop; 7) recurring psychological counseling; 8) conclusions regarding social and psychological readiness of the citizens to be mentors (as a result of the meeting of multidisciplinary team consisting of social worker/social counselor who conducted the coordination meeting and visited family, psychologist and trainers); 9) reciprocal selection of a child and a mentoring candidate according to child's needs and mentor's resources; 10) social and psychological support of child and mentor.

As we may see, the Mentoring Programme for orphans and children deprived of parental care involved the implementation of a training course for the citizens wishing to become mentors for orphans and children deprived of parental care in 2011. The aim of the course was training people who want to become mentors for the efficient interaction with orphans and children deprived of parental care. The tasks of the training course were the following: 1) to examine the system of orphans care in Ukraine; 2) to build a understanding of a displacement process in a child's life; 3 ) to reveal the role of mentor in orphan's life; 4) to analyse interaction peculiarities between mentor and orphan; 5) to present the Mentoring Programme for orphans.

According to the aim and the tasks, the structure of the training course was defined as follows:

- Session I: System of orphans care in Ukraine (tasks: to familiarize with the history of development of the orphans care system and the options for the orphans placement; to analyse the myths and stereotypes regarding the orphans in Ukrainian society; to reveal socialization peculiarities of the orphans in communal institutions); 
- Session II: Displacements in a child's life (tasks: to analyse possible options of a child's displacement; to examine the stages of a child's development; to familiarize participants with the notions "mental retardation (MR)", "intellectual disability", "deprivation or child hospitalism syndrome");

- Session III: Mentor's role in orphan's life (tasks: to familiarize with the notions and types of mentoring; to define the mentor's role in orphan's life; to analyse main qualities of the mentor; to define main mentor's competences; to examine the stages of development of mentoring interactions);

- Session IV: Peculiarities of interaction between mentor and orphan (tasks: to analyse child's behavioural peculiarities that complicate interaction between mentor and child; to define notions, types and the dynamics of the conflict; to place the emphasis on the thorny subjects for communication with orphan; to explain the notions "communication", "strategies", "tactics" and "styles" of efficient communication; to create the efficient communication skills);

- Session V: Mentor's resources in interaction with an orphan (tasks: to analyse the areas of personal development; to define the notions "genogram" and "eco-map"; to form practical skills of filling in the genogram and eco-map; to familiarize with the ideas of entertaining activities during the process of mentoring; to look for possible sources of knowledge enrichment and useful ideas regarding organization of the efficient work with a child);

- Session VI: Mentoring Programme for orphans (tasks: to examine the main goals, tasks and methods of Mentoring Programme's work; to define the possibilities of performance appraisal of mentor's activity; to present the video materials to the participants (interviews and motivational films) dealing with mentoring; to establish feedback with the participants of the training sessions).

Test results of implementation of the Mentoring Programme in Kyiv and Kyiv region in 2016 underlay the changes to the Law of Ukraine "On the provision of organizational and legal conditions of social protection for orphans and children deprived of parental care" dated $13^{\text {th }}$ January 2005 № 2342-IV [3]. In particular, the notions “mentor”, "mentoring” were introduced in the Article 1; in the Articles 17 and 39 the content of the mentoring was revealed and it was defined that in order to prepare the orphans and children deprived of parental care, as well as children belonging to this category to live independently, their social and psychological adaptation are entrusted to the Social services centres for families, children and 
youth, which was followed by a Cabinet of Ministers Decree dated $4^{\text {th }}$ July 2017 № 465 "On some issues of realization of mentoring towards a child” [9], by which Regulations of mentoring process and a Standardised mentoring contract were asserted.

According to the report of a NGO Odna nadiya (One hope), 170 mentors were undertaking their activities during 2010-2016. Out of them, 139 were mentors for one child, 27 mentors - for two children, 3 people became mentors for three children and 1 mentor - for four of them. Practically every mentor at different stages of interaction with a child came across difficulties in understanding and influencing child's behaviour, questions about their further interaction, lack of self-confidence and doubts concerning future work that demanded from the executors of programme the strengthening of the assistance component for the mentors. At the same time, numerous questions concerning the job content of the active mentors, who have already undergone training, indicated the need to reconsider the contents of the whole programme.

\section{Current needs and necessary support}

for the foster children residing in child care institutions

When the relationship between a child and their carer is the source of trauma, the attachment is being seriously violated. Child care characterized by contingency, hostility or offence makes a child feel helpless and abandoned. As a result, in order to cope with this situation, the child tries to take complete control over it, often by isolating himself/herself from social relationships or by violent actions towards the others. If trauma or oversight takes place at the beginning of a child's life, it may lead him/her to behavioural and psychological problems. Abandoned children and children who were physically abused learn to cope with threatening events and negative emotions through withdrawing into themselves and fencing themselves off the outside world. As a result, when they face some difficult situations, they cannot react adequately. Those children often have great difficulties in regulating emotions, showing concern for others and solving problems with the help of words. Adults, who experienced numerous unfavourable events during their childhood, are more disposed to hazardous behaviour, such as alcoholism, drug addiction, depression, suicide attempts, smoking, lack of physical activity, obesity, promiscuity (more than 50 sexual partners) and sexually transmitted diseases. The amount of negative experience 
in childhood is directly proportional to the amount of diseases in adulthood, including heart diseases, cancer, chronic lungs' diseases, skeleton factures and liver diseases [12]. Therefore, the help in overcoming the effects of cruel treatment experienced by institutions' foster children in childhood is, to our mind, one of the main tasks of a mentor.

In order to check our hypothesis concerning the current needs and necessary support for the foster children residing in child care institutions, we have conducted two series of focused group interviews: with boarding schools' foster children (3 groups, a total of 34 people) and with mentors ( 2 groups, a total of 17 people).

The first series of the focus-groups had the following tasks:

- analyse child's experience while undergoing important socialization stages under conditions of institutional care and to define the sources of support and activation of one's own resources used by the children on this route;

- define the needs and possibilities of supporting the children living in residential care institutions, their forms and types that may help children feel themselves safe and sound, protect themselves from violence and largely influence their own lives.

We outlined three main living stages, that participants of ther focusgroups went through in the context of institutionalization and which defined the topic of the interviews with each of the groups: 1) before institutionalization; 2) during institutionalization; 3) after leaving the institution. The discussion aimed at defining ther key critical points of children's life journeys and occurred taking into account both positive and negative moments of the acquired experience. The following key questions underlay the interview:

- What was the experience like?

- Were there periods or life situations when you felt insecure?

- What could adults, the society have given you at that moment? What could have helped you?

According to the young people, analysing their institutionalization experience, the most painful for them at that time was the problem of death of one of their relatives, highly traumatic events or emergencies (military operations, deprivation of liberty, unwanted pregnancy etc.); incapability of the adults responsible for them to react adequately to these events (alcohol, drugs, cruelty in family); unfavourable environment, which did not contribute to parents exercising their responsibilities in time and the absence of a safe place for a child to stay in. 


\section{Mentor's competence model used to build a relationship with a child living...}

While discussing their experience of staying in the residential care institution, young people were firstly expressing their concerns, trying to remember some positive moments of their life in the institution in the first place (lots of different hobby groups, artistic events, trips abroad etc.). They stated that even though it was a difficult period in their lives, they learnt plenty of things (discipline, tenacity). In due course the interviewees became more sincere and characterized their staying in the institution using such categories as unpleasant memories, wrong upbringing, cruelty, need to acquire authority; hunger due to the lack of products or because they were taken by the others, loss of personal belongings and lack of attention. The most critical situations for the participants when they felt very insecure were those when they were subjected to violence (including sexual) or there was such threat; they became victims of bullying or were humiliated by the staff of the institution (through punishment, e.g. after their attempt to escape from the institution) and they were isolated. In opinion of the youth, the following things could have improved the situation: personal relationship, presence of "second parents", foster parents, relatives; more freedom; preparation for living independently; meeting children living in families; no humiliation or sticking labels by the staff in the institution.

While analyzing their life experience after leaving residential carer institution, young people described it with the help of such categories as fear of the future; "clustering together"; search for work; alienation, expulsion, non-acceptance by the society (distrust, sticking labels, stigmatizing); reduced opportunities and lower self-esteem; lack of socialization skills; hot temper; injustice. Among the things that could have helped the participants were mentioned the following ones: presence of relatives, friends (mentors); help from the volunteers, church. Residential care institution leavers have such basic needs as legal assistance and support (first of all, provision of information); social ties (friends from church, local authorities); preparation for the job interviews, overcoming the ignorance; need for step by step instructions concerning actions of the leaver after leaving residential care institution; adaptation; help from the social worker/psychologist in the institution.

We conducted the second series of focus-groups in order to check our hypothesis concerning the basic elements of the future mentors training programme, that are defined by what mentors will have to face in the process of building of relationship with a child living in an institution. All the mentors went through the training according to the previous variant of the 
programme and had experience of mentoring one or more children. They were asked to analyze their experience in the context of participation in the mentoring programme, focusing their attention on two stages: 1) during the training before taking part in the programme and before the first contact with a child; 2) in the process of building a relationship and during the mentoring. The discussion occurred taking into account such aspects as the kind of help a child needs in order to overcome the consequences of the previous negative experience and whether the mentors have to be prepared to protect the children from the risks already existing in the children's lives or arising while being in a mentoring relationship. Key questions that participants were asked are the following:

- What knowledge and skills are important for mentors? What should be added or changed in the process of preparation to mentoring?

- What in the process of a mentoring relationship could serve as an anchor, what kind of help/support would be appropriate?

- Which are the indications of the efficiency of the mentoring relationship in the context of a child protection?

The participants almost unanimously acknowledged the importance of the preparation to mentoring alongside with the need to work further on the current programme. They stated that it is possible to improve the process of mentors training provided that the next elements are added: provision of the conditions for natural reciprocal selection, which occurs in the process of communication during group meetings between potential mentors and the institution's foster children; provision of knowledge on different types of violence, its signs and consequences; teaching how to act in case when a child's trauma is displayed; training on how to deal with the situation if the mentor reveals/suspects violence to which the child is currently subjected (action plan); training on how to talk to a child about violence if the issue arises (in situations when the child is a victim of violence and when he/she acts violently towards other children); mentors training on how to speak to other children living in the institution; involvement of active mentors in the learning process; provision of list of services and people to whom the mentor can address to get help (supervising authorities such as sanitary and epidemiological centre, doctors of various specialization profiles etc.); carrying out training that includes both basic mentors training and preparation based upon case study that would provide the understanding of the action plan in specific situations. 


\section{Mentor's competence model used to build a relationship with a child living...}

The participants of ther focus-group gave their recommendations to the mentors about acquiring knowledge and skills that would be important for acting effectively in the situations of child protection from the violence: knowledge and skills to define different types of violence; skills of giving a child advice concerning certain variants of protection from the violence; skills of searching for additional sources of information (literature, specialized internet resources, thematic conferences etc.); ability to build confidential relationship and create a safe environment for interaction with a child. Interviewees also stated that a sufficient factor of help to the mentor in their interaction with a child could be a possibility for a mentor to address another mentor who had a similar experience and namely had suffered from violence and overcame its consequences or whose "protégé" was abused in the same way and his/her mentor helped him to cope with it.

Mentor's competence can be assessed by the quality of relationship that he had built with a child and its effect on a child's life. Mentors referred the following to the list of things that can indicate the efficiency of mentoring relationship: 1) indications that show level of trust between child and mentor (child comes to meetings, is willing to communicate with the mentor; child asks his/her mentor for help in any difficult situations; child respects the opinion of the mentor and considers it; child largely reveals the "real" himself/herself; child naturally, without any pressure, accepts values of the mentor; the staff notice mutual positive opinions of mentor and child about each other); 2) signs that show changes in child's behaviour (fulfilment of an individual plan and reaching certain aims of mentoring; opinions of educators and specialists who previously worked with the child that prove positive changes in child's life or at least do not register negative changes and can be indirectly connected with influence of mentor; child learns, acquires knowledge, new competences, shows diligence, is eager to work; child smiles sincerely, shows positive emotions; child becomes less aggressive; child wishes to help the others; child reveals their artistic skills; child starts to demonstrate a thrifty attitude towards nature and animals; child assesses his/her possibilities more realistically, his/her complexes and fears disappear; child begins to have an idea about the future, is more confident; child does not harm himself/herself; child expresses desire of becoming a mentor for somebody else).

On the grounds of legal regulation of mentoring as a form of individual support and help to a child living in an institution for orphans and children 
deprived of parental care or other institution for children, helping them to prepare for living independently in the first place, as well as according to the studying of mentors' needs who participated in the Programme, Mentoring Project "Odna nadiya" ("One hope"), in collaboration with the NGO INTERNATIONAL LEADERSHIP AND DEVELOPMENT CENTER, has improved the mentoring programme and the Ministry of Social Policy has asserted it as The Programme of mentors training for working with orphans and children deprived of parental care (hereinafter referred to as Programme). The aim of the Programme is the development of necessary competences with the citizens regarding mentoring relationship with a child living in an institution for orphans and children deprived of parental care or other residential care institution for children and help them define their personal readiness and conscious decision regarding their participation in the mentoring. The Programme involves accomplishing the following tasks: 1) to reveal the content of mentoring as individual form of assistance for children living in orphanages and deprived of parental care or living in other institution for children; 2) to examine legal support of mentoring in Ukraine: procedure and conditions of mentoring; mentor's rights and responsibilities, duties of the social services centre for families, children and the youth, as well as duties of the residential care institution in the process of mentoring in the best interests of child; 3) to analyse socialization peculiarities of children living in the institution and characterize their psychological development and needs; 4) to form knowledge regarding peculiarities of building relationship between mentor and child in order to prepare him/her for living independently; 5) to understand and create awareness of importance of the teamwork with specialists both in the process of mentors training and supporting mentoring relations with a child.

Theme implementation plan of the Programme consists of the following structural components: 1 . Mentoring as individual form of supporting children living in an institution for orphans and children deprived of parental care or living in other type of institution for children; 2. Legal assistance of mentoring in Ukraine; 3. Socialization peculiarities of children living in the institution; 4. Displacements and losses in children's lives; 5. Specific characteristics of development of the children who need mentoring; 6. Mentor's role in the process of preparing children for living independently; 7. Building a relationship between mentor and child; 8 . Teamwork in the mentoring process. 


\section{Mentor's competence model used to build a relationship with a child living...}

The Programme is improved in its part concerning legal support of mentoring in Ukraine, and namely, regarding the procedure of mentoring activities aimed at a child (mentoring procedure and conditions); requirements to the mentor, description of his/her rights and responsibilities; description of rights and responsibilities of social services centre for families, children and the youth, as well as of an institution where the child lives in the process of mentoring in the best interests of child. The issue "Psycho-traumatic experience in a child's life as a consequence of displacements, losses and abuse" is revealed in detail and particularly the problem of influence of the violence to the psychological development and personality formation of a child is examined in depth. The notions "psychological trauma", post-traumatic stress disorder and signs of psychological trauma and post-traumatic stress disorder of children are revealed too. Regarding the issue of the "Specific characteristics of development of the children who need mentoring", apart from peculiarities of child's development under unfavourable socializing conditions (difficult life circumstances, losses, violence etc.) and experience of living in residential care institution, the notions "temperament" and "character" are examined and differentiated. The traits of character and conditions of their formation are analysed as well. At the same time the notion of "behaviour" is exposed and the factors that affect behavioural activities, as well as those which regulate behaviour are examined too. The behavioural exposures of a child that complicate the process of communication and interaction with their are characterized. The mechanisms of psychological protection of children as a result of difficult life circumstances are examined.

The notion "identity", formation and development of identity of a child, as well as meaning of identity in child's life are widely exposed in the Programme.

Apart from the social and psychological aspects of meeting and establishing contact between mentor and child, the Programme includes the analysis of procedure of meeting organization and establishing contact between mentor and child which is defined by the Cabinet of Ministers of Ukraine Decree dated $4^{\text {th }}$ July 2017 № 465 “On some issues of realization of mentoring towards a child" [9].

The Programme is also supplemented regarding the part of teamwork in process of mentoring. The personnel of a team in process of mentoring, peculiarities of interaction between mentor and representatives of Social 
services centres for families, children and youth, Child protection services, directors of institutions are examined. The resource of a team in process of preparing child living in an institution for the independent living is defined.

\section{Mentor's competence model}

Competence is the necessary quantity and level of knowledge, skills and experience in a certain type of activity. In the UNESCO reports the notion of competence is interpreted as a combination of knowledge, skills, values and attitudes applied in everyday life [18, p. 5]. I.e. competence is viewed as an ability to apply knowledge and skills effectively and in a creative manner in personal relationship - situations which require interaction with other people in social context, as well as in professional life. Competence is a notion, which exposes the route from attitudes to values and from skills to knowledge.

On the grounds of proposed Mentoring Programme for orphans and children deprived of parental care and within the framework of implementation of the Mentoring Project "Odna Nadiy" ("One Hope"), INGO Odna Nadiya (One Hope) alongside with Child protection service of Kyiv city have defined a mentor's basic competences:

- life skills competence is knowledge about different aspects of person's life, skills of a creative use of intellectual and physical instruments, ability to interact with other people in different situations including conflict ones, characterizes the completeness, sufficiency and adequacy of actions that are based upon knowledge and experience. Basic principles of life competence (according to UNESCO concept) are: learning to learn, learning to work, learning to live;

- professional skills competence is the ability of a person the basis of which is formed by his/her experience, knowledge and skills to complete tasks effectively that refer to the field of his/her professional activity;

- social skills competence is an acquired ability of personality to remain flexible in permanently changing social circumstances and interact with the social environment effectively;

- communicative skills competence is an ability to undertake and perform various social roles; ability of a person to adapt to various situations, free use of verbal and non-verbal communication skills; one of the indicators of communicative competence is the ability to listen;

- cultural competence includes knowledge and acceptance of national and basic human values that underlie the behaviour of a person. It is an 


\section{Mentor's competence model used to build a relationship with a child living...}

ability to recognize and consider cultural values that differ from one's own culture.

In comparison with the previous Mentoring Programme, the new Mentors training programme that is adopted at the state level, has specified the basic knowledge and skills of a mentor. And in particular, knowledge needed for people who build mentoring relationship with a child are defined as follows:

- content of mentoring: aim, main tasks, form and areas;

- roles, qualities and competences of a mentor;

- legal support of mentoring in Ukraine: requirements to the mentor, his/her rights and responsibilities;

- influence of orphanhood on a child's development;

- meeting organization and establishing contact between mentor and child;

- stages of development of mentoring relationship with a child;

- rules and techniques of efficient communication with a child;

- criteria of effective mentor's performance;

- interaction between mentor and representatives of state authorities: Social services centres for families, children and youth, Child protection services, heads of institutions etc.

The Programme includes formation of the following skills with its participants:

- to apprehend adequately and be tolerant towards a child, who has an experience of being displaced, lost relatives and close people due to difficult life circumstances;

- to establish contact with a child during the meeting in the institution;

- to give support to a child who experiences loss or reveals signs of other traumatic events;

- to react adequately to unpredictable child's behaviour;

- to apply techniques of efficient communication with a child, taking into account his/her social environment and specific characteristics of his/ her psychological development;

- to build positive self-awareness with a child, to encourage feelings of his/her own dignity and self-respect;

- to facilitate the development of child's potential, self-confidence, building relationships in society, cultural and moral values;

- to develop his/her practical and communication and self-presentation skills, to encourage healthy lifestyle, to help overcome difficulties, to teach 
about housekeeping, to dispose his/her personal property and means of living, to teach everyday skills, to help a child in education and professional self-determination;

- to facilitate the acquisition of educational, social, medical, administrative and other services by a child;

- to encourage and help a child in developing new positive social connections and renewing (building) relationship with his/her biological parents;

- to assess the efficiency of mentoring.

The analysis of training experience of people willing to become mentors, as well as the results focus-groups allows us to propose a mentor's competence model which consists of the mentor's ability to fulfil the needs of a child. Basic components of this model include: fulfilment of a child's needs in communication and close emotional contact with a reliable person; fulfilment of a child's needs in protection and support by a reliable person; fulfilment of a child's needs in development; fulfilment of a child's needs in socialization (forming skills for living independently); fulfilment of teenagers' needs in professional orientation (see Pic. 1). Knowledge and skills necessary for understanding and implementing the above mentioned needs define the readiness of a person to mentoring.

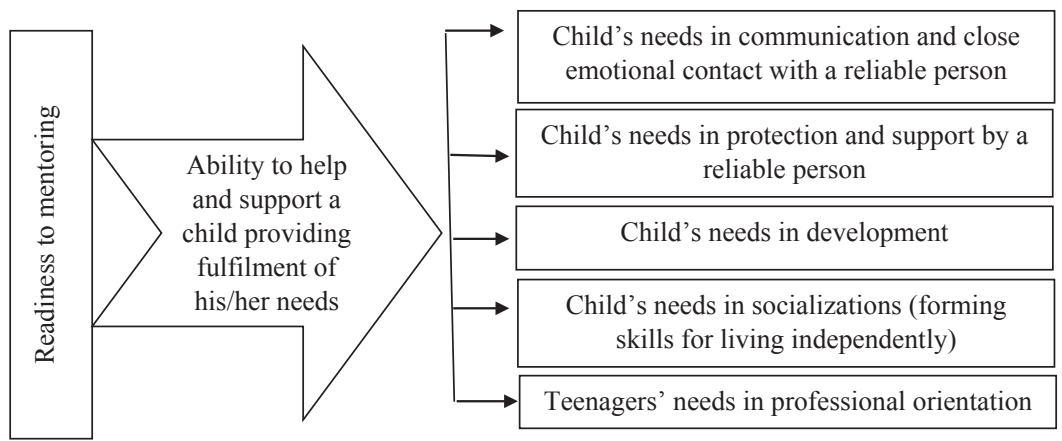

\section{Picture 1. Mentor's competence model}

The stated mentor's competences will facilitate personal development of the children living in a residential care institution, their preparation for independent personal life and professional activities. Competence approach aimed at the needs of children of this category will improve the quality of their lives in the context of adding value to a child's personality, 
his/her adaptation, flexibility in social life as a whole and in particular, will enhance his/her competitiveness at the labour-market. And namely the fulfilment of the above mentioned needs of the children living in a residential care institution through mentoring will give them a possibility to get rid of feeling of isolation, needlessness and on the contrary, feel individually significant and secure. The presence of a mentor in a child's life will stimulate his/her individual growth, boost successful social life, make wise life choices.

\section{Conclusions}

The review of theoretical approaches to studying the content of mentor's competences needed for interaction with a child living in an institution let us single out two main points. European and American scientists stress out the following tasks of interaction between a child and a mentor: assistance in overcoming consequences of psycho-traumatic experience of a child and protection of a child from the possible risks connected with abuse and neglect. The research by our Ukrainian colleagues sees assistance in overcoming psychological problems connected with institutionalization of a child and preparing him/her for living independently as the main task of a mentor. We have also defined the basic knowledge and skills of a mentor, which became the basis for the training programme for people who want to become mentors in Ukraine. The analysis of empirical data collected as a result of mentoring project implementation in Kyiv city and Kyiv region by NGO Odna Nadiya (One Hope) indicated the necessity of improving the programme to provide quality training to mentors in fulfilling the needs of children, who live in the institutions, and providing these children with all support necessary. In particular, the mentors' training has to be intensified in the context of deepening knowledge regarding influences of psycho-traumatic experience on the formation and development of a child's personality, impact of unfavourable socialization conditions experienced by a institutionalised child, as well as problems concerning identifying signs and understanding consequences of various types of abuse, and recommendations on mentor's actions in case of identifying such signs. The opinions of mentors regarding the benefits and critical necessity of forming competences to counteract the child abuse must be considered and reflected in the process of development and implementation of corresponding programme components in future training for mentors. 
Overall, the results of this research let us develop the mentor's competence model in building relationship with a child, who lives in an institution for orphans and children deprived of parental care or other child care institution. The basis of the model includes key mentor's competences aimed at fulfilment of the needs of children, who live in residential care institutions. The groups of needs are: needs of communication and close emotional contact with a reliable person; needs of protection and support by a reliable person; personal growth needs; socialization needs (forming skills of independent living); professional orientation needs. The prospects of further research are: the analysis of monitoring data that will be collected during scaling up the mentoring project to the national level; study of mentorship practice peculiarities with groups of children of different age, state of health and social status, as well as an elaborate study of the mentors' needs in training and support while working with such children.

\section{References:}

1. Balakirieva O. M., Chernin I. M., Khmelevska O. M. et al. (2010) Analitychnyi zvit "Zhyttievyi shliakh vypusknykiv internatnykh zakladiv, dytiachykh budynkiv simeinoho typu ta pryiomnykh simei" (za rezultatamy sotsiolohichnoho opytuvannia) [Analytical report "Life way of graduates of residential institutions, family-type orphanages and foster families" (according to the results of a sociological survey)], Kyiv.

2. Hluzman O. V. (2009) Bazovi kompetentnosti: sutnist ta znachennia v zhyttievomu uspikhu osobystosti [Key competences: the essence and significance in the life success of a personality]. Pedahohika i psykholohiia, no 2, pp. 51-61.

3. Zakon Ukrainy "Pro zabezpechennia orhanizatsiino-pravovykh umov sotsialnoho zakhystu ditei-syrit ta ditei, pozbavlenykh batkivskoho pikluvannia" vid 13 sichnia 2005 roku No. 2342-IV (zminy, vneseni zghidno iz Zakonom № 1504VIII vid 8.09.2016) [Law of Ukraine "On the provision of organizational and legal conditions of social protection for orphans and children deprived of parental care" of January 13, 2005, No. 2342-IV (amendments made according to the Law No. 1504-VIII dated September 8, 2016)] (n.d.). Electronic resource. Retrieved from: http://zakon2.rada.gov.ua/laws/show/ru/1504-19 (accessed 20 February 2018).

4. Kapska A. Y., Piesha I. V. (2012) Sotsialnyi suprovid riznykh katehorii simei ta ditei : navch. posib. [Social support for different categories of families and children : tutorial]. Kyiv : Tsentr uchbovoi literatury. (in Ukrainian)

5. Kryzhanivska O. P., Stepanenko H. V. (2010) Zhyttieva nekompetentnist vykhovantsiv internatnykh zakladiv [Life incompetence of boarding school students]. Visnyk NTUU “KPI". Politolohiia. Sotsiolohiia. Pravo : zbirnyk naukovykh prats, no. 4 (8), 147-150.

6. Kovaleva N. V., Detkova I. V., Leont'eva A. V. et al., E. N. Panchenko (ads.). (2006) Nastavnychestvo kak protsess soprovozhdenyia detei y podrostkov "hrupp 


\section{Mentor's competence model used to build a relationship with a child living...}

ryska" : sbornyk nauch.-metod. materyalov [Mentoring as a process of escorting children and adolescents of "risk groups" : a collection of scientific and methodological materials]. Moscow: Maikop. (in Russian)

7. Smal' E., Satsiuk Y., Androsova V. et al. (2012) Nastavnichestvo shag za shagom. Posobie dlya neravnodushnykh vzroslykh [Mentoring step by step. Handbook for non-caring adults]. Kiev: Proekt Nastavnychestva ODNA NADEZhDA. (in Ukrainian)

8. Kanishevska L. V., Kuzmenko L. V., Svyrydenko S. O. et al. (2013) Pidhotovka uchniv internatnykh zakladiv do zhyttiediialnosti $u$ vidkrytomu suspilstvi : navch.metod. posibnyk [Preparation of boarding school students for life in an open society: teaching method. manual]. Kirovohrad: Imeks-LTD. (in Ukrainian)

9. Postanova Kabinetu Ministriv Ukrainy "Deiaki pytannia zdiisnennia nastavnytstva nad dytynoiu" vid 4 lypnia 2017 r. No 465 [Resolution of the Cabinet of Ministers of Ukraine "On some issues of realization of mentoring towards a child" of July 4, 2017, No. 465.]. (n.d.). Electronic resource. Retrieved from: http://zakon3.rada.gov.ua/laws/show/ru/465-2017-\%D0\%BF (accessed 20 February 2018).

10. Udovenko, Yu., Smal, O. (2012) Metodychnyi posibnyk do vprovadzhennia Prohramy nastavnytstva dlia ditei-syrit ta ditei, pozbavlenykh batkivskoho pikluvannia [Methodical Manual for the Implementation of Mentoring Programs for Orphaned Children and Children Deprived of Parental Care]. Kyiv. (in Ukrainian)

11. Barter, C., Renold, E., Berridge, D. \& Cawson, P. (2004). Peer Violence in Children's Residential Care. Palgrave Macmillan UK, 249.

12. Felitti, V. J., Anda, R. F., Nordenberg, D., Williamson, D. F., Spitz, A. M., Edwards, V. \& Marks, J. S. (1998). Relationship of childhood abuse and household dysfunction to many of the leading causes of death in adults: The adverse childhood experiences (ACE) study. American Journal of Preventive Medicine, 14 (4), 245-258.

13. Hobbs, G. F., Hobbs, C. J. \& Wynne, J. M. (1999, December). Abuse of children in foster and residential care. Child Abuse \& Neglect, Vol. 23, Issue 12, 1239-1252.

14. Jekielek S., Moore K. A., \& Hair E. (2002, January). Mentoring Programs and Youth Development: A Synthesis. Washington, DC: Child Trends, 68.

15. Loman L. A. \& Siegel G. L. (2000, November). A Review of Literature on Independent Living of Youths in Foster and Residential Care. A Report of the Institute of Applied Research. St. Louis, Missouri. Retrieved from: http://www.iarstl.org/papers/IndLivLit.pdf (viewed on February 20, 2018).

16. No Way Home. The Exploitation and Abuse of Children in Ukraine's Orphanages (2015). Electronic resourse : [Ukrainian Executive Summary (.doc)]. Retrieved from: https://www.driadvocacy.org/media-gallery/our-reports-publications/ (viewed on February 20, 2018).

17. Osborn, A. \& Bromfield, L. (2007, October). Young people leaving care. Electronic resourse. NCPC Brief No.7. Retrieved from: https://aifs.gov.au/cfca/ publications/young-people-leaving-care (viewed on February 20, 2018).

18. Ruchen, D. S. (2003). Key Competencies for a Successful Life and a WellFunctioning Society. Hogrefe \& Huber Publishers, Germany, 4-5. 